\title{
半永久型3次元光メモリの開発
}

\author{
下間 靖彦 ${ }^{1}$ ，三浦 清貴 ${ }^{1}$, 坂倉 政明 ${ }^{2}$, \\ 塩澤 学 $^{3}$, 今井 亮 $^{3}$, 渡部 隆夫 ${ }^{3}$, 渡辺 康一 ${ }^{3}$ \\ 1京都大学大学院 工学研究科材料化学専攻 ( ₹ 615-8510 京都市西京区京都大学桂) \\ 2京都大学 産官学連携本部（テ615-8520 京都市西京区御陵大原 京都大学イノベーションプラザ204） \\ ${ }^{3}$ (株) 日立製作所中央研究所（１１85-8601 東京都国分寺市東恋ヶ窪1-280）
}

\section{Development of 3D Optical Storage with Super Long-Term Stability}

\author{
Yasuhiko SHIMOTSUMA, ${ }^{1}$ Kiyotaka MIURA, ${ }^{1}$ Masaaki SAKAKURA, ${ }^{2}$ Manabu SHIOZAWA, ${ }^{3}$ \\ Ryo IMAI, ${ }^{3}$ Takao WATANABE, ${ }^{3}$ and Koichi WATANABE ${ }^{3}$ \\ ${ }^{1}$ Department of Material Chemistry, Kyoto University, Kyotodaigaku-Katsura, Nishikyo-ku, Kyoto 615-8510 \\ ${ }^{2}$ Office of Society-Academia Collaboration for Innovation, Kyoto University \\ Innovation Plaza 204, Goryo-ohara, Nishikyo-ku, Kyoto, 615-8520 \\ ${ }^{3}$ Hitachi, Ltd., Central Research Laboratory, 1-280, Higashi-koigakubo Kokubunji-shi, Tokyo, 185-8601
}

(Received July 8, 2013)

\begin{abstract}
3D optical storage technology to record digital data with a femtosecond laser and read with a microscope inside fused silica. The recorded sample has a high thermostability $\left(>1000{ }^{\circ} \mathrm{C}\right)$ and indicates semipermanent preservation of valuable information such as a cultural heritage. Unexpected periodic nanostructures beyond the diffraction limit of light are also observed in recorded sample. Such selfassembled nanostructures produced by femtosecond laser direct-writing in fused silica and nonreciprocal modification originated from the anisotropic thermalization by the pulse-front-tilt are also reported.
\end{abstract}

Key Words: 3D optical storage, Femtosecond laser, Fused silica

1. はじめに

ガラスの起源としてよく引き合いに出される話は, 古 代ローマのプリニウスによる「博物誌」の中のエピソード である。これは,「フェニキア人がベールス河の岸で食 事の準備をするとき, ソーダ塊を支えにして火にかけた ところソーダと砂が融け合ってガラスになった.」という ロマン溢れる話である. 現在, 数千年の時を超えたガラ スが発見されている。このようにガラスは，ステンドグ ラスをはじめとして，私たちに光の美しさを印象付けて くれるだけでなく, 特に石英ガラスは, 耐火性, 耐熱衝 撃性, 耐水性, 化学的安定性に優れた機能性材料の一つ である。一方で, 昨今のデジタル放送やブロードバンド 通信の普及に伴い, 大容量のデジタルデータのストレー ジ技術が要求される. 現在, 光メモリの高密度化技術と しては, 近接場光学の利用, 多值・多層化, ホログラム 記録等が提案されている。現在ハードディスクや光ディ スク，磁気テープなどが用いられており，これらに記録 したデータの寿命は，温度や湿度の管理が十分になされ た状態で10年から 100 年と言われている。 一方, 恒久的
な保存が求められる歴史上重要な文化遺産や歴史的公文 書などにおいては，温度や湿度などによる記録データの 経年劣化がなく，いつの時代にも記録デー夕を読み出す ことができるストレージ技術が必要である。これまでに 我々は, フェムト秒レーザーの集光照射により石英ガラ スに記録した情報が数億年の寿命 (室温)を持つ可能性を 示し, 空間光位相変調器を活用した多数のビット情報を 一括で記録する技術および，低倍率の顕微鏡で検出した データを簡単な画像処理でデジタルデータとして読み出 す技術を開発してきた。本稿では，フェムト秒レーザー と石英ガラスの相互作用, 特に大容量化に繋がるナノ周 期構造の自己組織化, さらに書き込み時に見られる非相 反的な相互作用について概説する.

\section{2.フェムト秒レーザーによる光誘起構造}

2.1 石英ガラス内部における光誘起構造の分類

フェムト秒レーザーは，パルス幅が電子とフォノンの カップリング時間(ピコ秒オーダー)よりも短く, レンズ で集光することによって，容易に数百 $\mathrm{TW} / \mathrm{cm}^{2} も の$ 高い 
パワー密度を達成できるため, 材料表面を含めた任意の 部位において，様々な高次の非線形光学現象を誘起する ことが可能である ${ }^{1)}$ 。これまでに我々は, フェムト秒 レーザーを光源として透明な材料の内部に集光照射する ことにより，伯形成や活性イオンの酸化還元による着 色 $^{2,3)}$, 構造の高密度化による屈折率変化 ${ }^{4-6)}$, 溶融や衝 撃波発生 ${ }^{7-9)}$, オプティカルブレークダウンによる転位 やクラック，ボイド形成 ${ }^{10-12}$ 等の様々な現象を発現して きた，特に，石英ガラスの場合，集光照射するフェムト 秒レーザーの強度に伴い，その焦点に誘起される構造は 次の3種類に大別できる：(1)正の屈折率変化領域 (タイプ I), (2)複屈折構造 (タイプII), (3)空孔欠陥からなるダ メージ構造 (タイプIII)がそれぞれ誘起される ${ }^{13)}$. これま でにタイプIの誘起構造は, 光導波路 ${ }^{6}$ やカプラ ${ }^{14)}$ 等の光 デバイスへの応用の可能が示されている. タイプIIIで は, 光メモリ ${ }^{10)}$ やフォトニック結晶 ${ }^{15)}$ 等への応用研究が 進められている。中間のタイプIIは，Geを゙ープした石 英ガラスにおいてレーザー照射中にその偏光方向に依存 した異方性光散乱としてKazanskyらによって最初に観測 された ${ }^{16)}$. またMysyrowiczらはタイプIIの誘起構造が一 複屈折を示すことを明らかにした ${ }^{17)}$. 我々は, 集光部に ナノ周期構造が自己組織化的に形成されている様子を電 子顕微鏡で直接観察することに初めて成功した。さら に, 非線形過程によりプラズマ電子が励起され ${ }^{18)}$ ，レー ザー光と励起されたプラズマ電子波の干渉により，ナノ 周期構造が形成すると考えた ${ }^{19,20)}$ 。最近では，フェムト 秒レーザーのシングルパルス照射でナノ周期構造が観察 されないことから, ナノプラズマに基づいた欠陥の自己 組織化等のモデルも提案されている ${ }^{21)}$.

\section{2 光誘起屈折率変化領域の光メモリへの応用}

フェムト秒レーザーによる誘起構造を石英ガラス内部 に3次元積層にすることによって, 高密度な光メモリと して期待できる。具体的には, 石英ガラス内部の屈折率 変化の有無と記録データの 0,1 とを対応させることで, デジタルデータとして記録した。特に空間光位相変調器 により光の位相を2次元的に変調させ, 単一スポットか ら任意のパターンの多スポットを生成することによっ て，複数のデータビットの高速な一括記録を実現でき る。また再生方法については, 長期保存後の状況を考慮 し, 比較的低倍のレンズ (20倍程度)を用いた一般的な光 学顕微鏡を再生装置とし, これに対応する信号処理技術 によって, 光誘起屈折率変化領域を強調することで, デ ジタルデータを高S/N比で読み出すことに成功した。

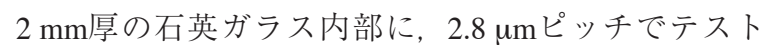
パターンを最大で4層記録し, 記録パターンを20倍の低 倍率顕微鏡で観察した像および信号処理後にデジタル データとして再生した像をFig. 1に示す.S/N比 $15 \mathrm{~dB} 4$ 層で達成し, 平面記録密度はCDの記録密度を上回る $40 \mathrm{MB} / \mathrm{inch}^{2}$ の記録再生が可能であることを確認した。 記録済みサンプルの高温加速試験の結果をFig. 2に示 す. $700{ }^{\circ} \mathrm{C}, 900{ }^{\circ} \mathrm{C} に お け る$ 劣化具合のアレニウスプ ロットにより，室温での寿命が3億年程度と見積もっ

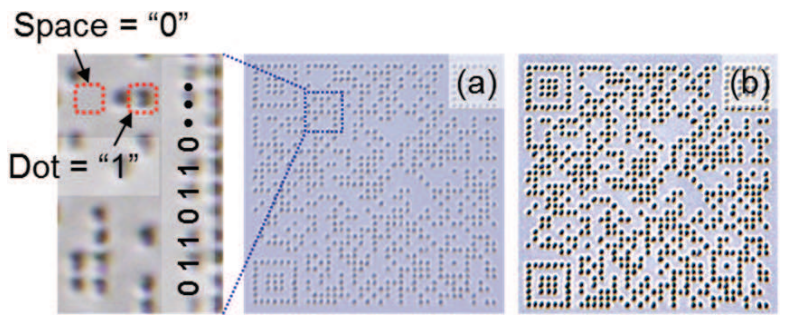

Fig. 1 (a) Image of the recorded sample taken with optical microscope. (b) Enhanced contrast image by signal processing. High magnified image is also shown. Dot and non-recorded area (space) correspond to data of " 1 " and " 0 ", respectively.

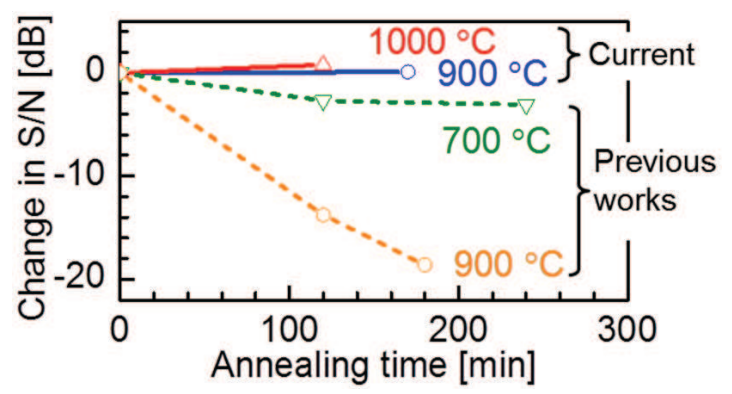

Fig. 2 Annealing-time dependence of change in $\mathrm{S} / \mathrm{N}$ ratio. Solid lines are current results at $900{ }^{\circ} \mathrm{C}$ and $1000{ }^{\circ} \mathrm{C}$ for $2 \mathrm{hr}$. Dashed lines are previous works. ${ }^{22)}$

た22)、今回，記録条件を最適化することで，更に厳しい 加熱試験 $\left(1000{ }^{\circ} \mathrm{C} て ゙ 2\right.$ 時間)の後も画像デー夕に劣化がな いことを確認した。このことから室温での寿命は，ほぼ 半永久的と予想した。 なお，高温劣化がない試料の誘起 構造がどの夕イプであるかは今後の詳細な分析が必要で あるが, 少なくとも高温劣化した試料は, タイプIの構 造が弱く誘起されていたと考えられる.

\section{3 光誘起ナノ周期構造の光メモリへの応用}

タイプIIの誘起構造の模式図をFig. 3に示す。この構造 は, 酸素欠陥により屈折率が低くなった領域 $\left(n_{1}\right)$ と相対

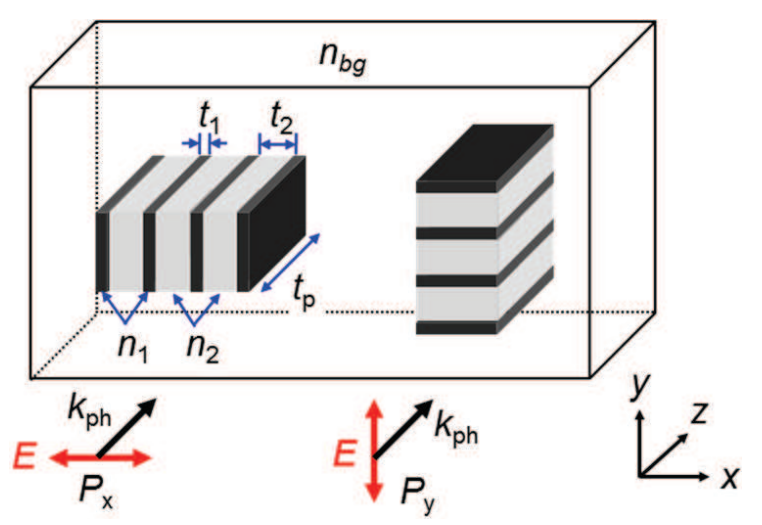

Fig. 3 Schematic of the self-organized nanostructure. $E$, $k_{\mathrm{ph}}$ : electric field, wave vector of the writing laser of $P_{\mathrm{x}}$ or $P_{\mathrm{y}} \cdot n_{\mathrm{bg}}, n_{1}, n_{2}$ : refractive index of bulk silica glass, local indices of the nanostructure with width of $t_{1}, t_{2}$, respectively. $t_{\mathrm{p}}$ : thickness of nanostructure. $\Lambda=t_{1}+t_{2}$ : period of the nanostructure. 
的に屈折率が高くなった領域 $\left(n_{2}\right)$ が照射レーザーの偏光 に垂直な方向に光の波長よりも10倍程度短い周期で形成 されるため，複屈折を示すことが予想される，実際に， タイプIIが示す複屈折 $\left(\Delta n=n_{1}-n_{2}\right)$ について，干渉縞を 利用した位相ステッピング法 ${ }^{23)} に よ り$ 測定した結果, $\Delta n=-0.1$ であり, 負の構造性複屈折を示すことがわ かった。

ナノ周期構造の形成過程を明らかにするため, シング ルショットでの実験を行った(Fig. 4). 実験で使用した フェムト秒レーザーパルスは，波長 $800 \mathrm{~nm}$ ，パルス幅 70 fsであり，対物レンズ $(100 \times 0.90$ N.A. $)$ を通して合成 石英ガラスの表面から約 $100 \mu \mathrm{m}$ 内部に集光照射した。 照射するパルスエネルギーは約 $1.0 \mu \mathrm{J}$ とし, 対物レンズ 後のレーザー光の強度は偏光方向に関係なく一定であっ た。用いたレーザーパルスの既定の繰り返し周期は $250 \mathrm{kHz}$ であり，これはパルス間隔が4 usに相当する。 パルス間隔 $\left(\tau_{\text {int }}\right)$ と照射パルス数 $\left(N_{\text {pulse }}\right)$ は $250 \mathrm{kHz}$ の増幅 器にトリガ電気パルスを入力することにより制御した。 シングルショットでは，照射エネルギーを増加させても 明確なナノ周期構造の形成は確認できず，集光部にレー ザー光の強度分布に応じて酸素欠陥が一様に形成した。

また，集光部周辺には応力に由来した複屈折が観察され た。一方，複数のパルス照射後には，幅約 $20 \mathrm{~nm}$, 周期 間隔150 $\mathrm{nm}$ 程度の酸素欠陥からなるナノ周期構造が形 成した。この結果は，集光部に誘起された酸素欠陥が $N_{\text {pulse }}$ の増加に伴い, 徐々にナノ周期構造へと自己組織化 されることを示唆している。 このような現象は, 外村ら による電子での二重スリットの実験で干涉パターンが 徐々に形成される様子 ${ }^{24)}$ と似ている。

$\tau_{\text {int }}$ および $N_{\text {pulse }}$ を変化させたフェムト秒レーザーの集光 部において, ナノ周期構造の形成に由来した複屈折の位 相差(リターダンス)がどのように変化するかを偏光顕微

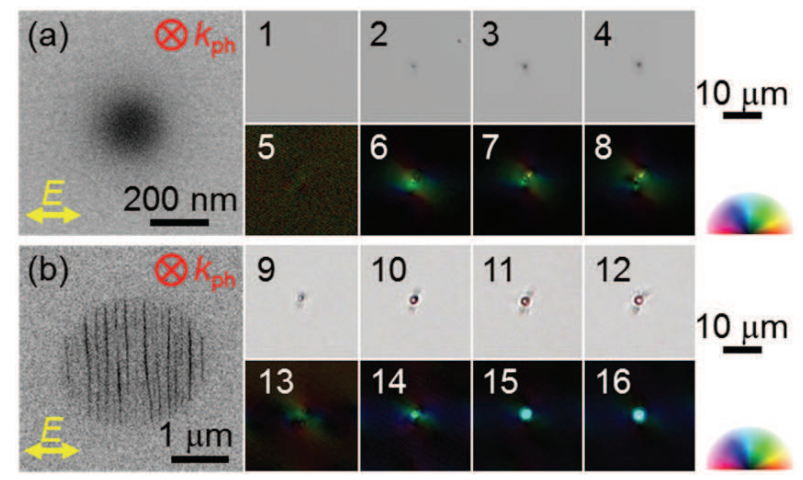

Fig. 4 Backscattering electron images of the modified structures by the single-pulse $\left(N_{\text {pulse }}=1\right)$ (a) and multiple-pulses $\left(N_{\text {pulse }}=1000\right)(\mathrm{b})$. Images taken with optical $(1-4,9-12)$ and polarized $(5-8,13-16)$ microscope of the modified regions are also shown. Images of (1-8) show the results by the singlepulse with a different pulse energy of $(1,5) 0.4 \mu \mathrm{J}$, $(2,6) 1.0 \mu \mathrm{J},(3,7) 1.6 \mu \mathrm{J}$ and $(4,8) 2.0 \mu \mathrm{J}$, respectively. Images of (9-16) show the results by the multiple-pulses of $1.0 \mu \mathrm{J}$ with a different $N_{\text {pulse }}$ of $(9,13) 10,(10,14) 100,(11,15) 500$ and $(12,16)$ 1000 pulses, respectively.
鏡で観測した(Fig. 5)。なお，パルスエネルギーは1.0 $\mu \mathrm{J}$ とした． $N_{\text {pulse }}$ の増加に伴い, リターダンスは増加した。 また $\tau_{\text {int }}$ が100 $\mu \mathrm{s} よ り$ 短い(レーザーパルスの繰り返し周 期が $10 \mathrm{kHz}$ より高い)場合，同じパルス数照射したにも かかわらず，リターダンス值は小さく， $\tau_{\text {int }}$ が100 usより 長い場合はほぼ一定值となった。これは， $\tau_{\text {int }}$ が短くな るにしたがい，熱蓄積の効果がより大きくなることと関 係していると考えられる。フムト秒レーザーを石英ガ ラス内部に集光照射すると，レーザーエネルギーは，非 線形吸収やその後のプラズマ発生による逆制動放射等の 過程を経て石英ガラス内部の集光部近傍に注入され，集 光部の温度が急激に上昇する。この時, 衝撃波の発生や 伝搬に加え，非架橋酸素や酸素欠陥等が生成する。逐次 的なレーザーパルスの照射により，条件によっては，熱 蓄積が起こるものの, 数 $\mu$ 後には熱拡散によって温度は 急激に低下する ${ }^{25)}$ 。この急激な温度変化によって緩和さ れずに凍結された欠陥の量が， $\tau_{\text {int }}$ に応じた熱蓄積の度 合いによって，変化するためと考えられる．

さらに興味深いことに，同一のパルスエネルギーであ るにもかかわらず, リターダンスの変化が偏光方向に依 存した。 ガラスは等方性材料であるため, このような異 方性の強い相互作用は，材料由来ではない。フコムト秒 レーザーパルスの空間的なチャープやパルス面傾斜等が 関係していると推測される。さらに照射部の構造変化を 詳細に評価するため， $\tau_{\text {int }}$ および $N_{\text {pulse }}$ を変化させ，集光部 におけるリターダンスおよびラマンピーク強度比を測定 した(Fig. 6).

ラマンスペクトル解析は, 非架橋酸素や酸素欠陥由来 の蛍光をバックグラウンドとして除去した後，ラマン散 乱の温度及び周波数依存性を補正した ${ }^{26)}$ 。なお，測定し たラマンスペクトルのピークはすべて既知のものであっ た27). 例えば, $450 \mathrm{~cm}^{-1}$ 付近のメインピークはSi-O-Si変 角振動由来のブロードなピーク, $800 \mathrm{~cm}^{-1}$ 付近にO-Si-O の対称伸縮振動, $490 \mathrm{~cm}^{-1}, 600 \mathrm{~cm}^{-1}$ 付近にそれぞれ $\mathrm{Si}-\mathrm{O}$ 網目構造中の4員環構造, 3員環構造に由来したD1, D2ピークが観察された。D1およびD2ピークは石英ガラ ス内部のSi-O網目構造の緻密化を推測する上で大変重要 であり, レーザー照射による変化が小さいと考えられる $800 \mathrm{~cm}^{-1}$ 付近の基本振動ピークの強度 $\left(v_{\mathrm{Si}-\mathrm{O}}\right)$ に対するD2

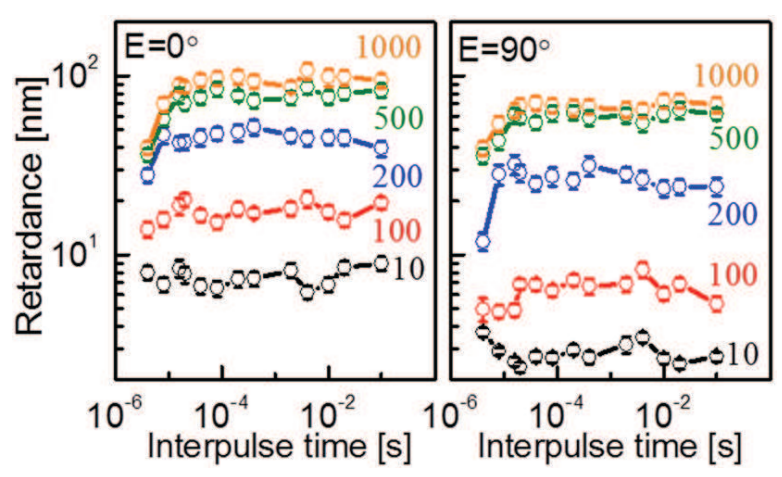

Fig. 5 Evolution of retardance value for two orthogonal polarizations $\left(\mathrm{E}=0^{\circ}\right.$ and $\left.90^{\circ}\right)$ as a function of $\tau_{\text {int }}$ with different $N_{\text {pulse }}$ of 10,100, 200, 500 and 1000, respectively. The pulse energy was fixed at $1.0 \mu \mathrm{J}$. 
(a)
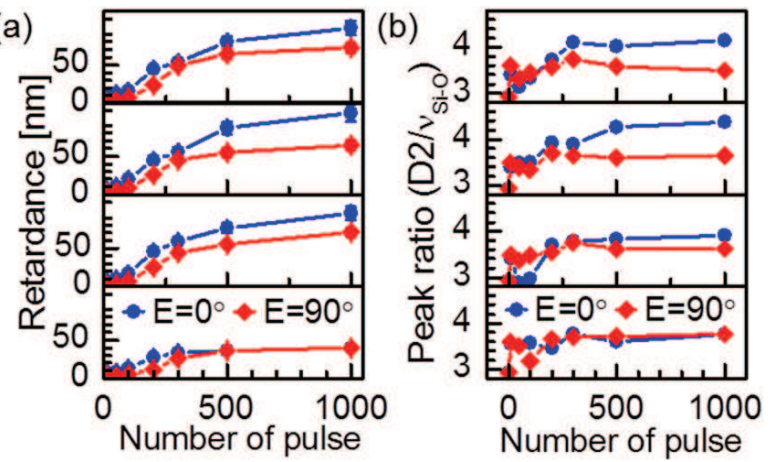

Fig. 6 Difference in the evolution of retardance (a) and Raman peak ratio of $\mathrm{D} 2$ to $v_{\mathrm{S} \text {-O }}$ (b) between the orthogonally polarized pulses $\left(\mathrm{E}=0{ }^{\circ}\right.$ and $\left.90^{\circ}\right)$ as a function of $N_{\text {pulse }}$ with the different $\tau_{\text {int }}$ of $20 \mathrm{~ms}$, $4 \mathrm{~ms}, 40 \mu \mathrm{s}$ and $4 \mu \mathrm{s}$ (top-to-bottom), respectively.

ピーク強度に着目し，プロファイルを得た。 $N_{\text {pulse }}$ が100 パルス以下では， $\tau_{\text {int }}$ に関係なく，リターダンス，D2ラ マン強度は増加し， $N_{\text {pulse }}$ が約 300 パルス以降はリターダ ンス，D2ラマン強度ともに飽和した。 これは, レー ザー照射初期に見られる急激な温度変化に伴う応力由来 の複屈折からナノ周期構造の形成に起因した構造性複屈 折へと変化している様子を示していると考えられる。こ の結果は，誘起される複屈折のリターダンス值は $\tau_{\text {int }}$ お よび $N_{\text {pulse }}$ によって制御可能であることを示している.

これまでに照射パルスエネルギーを増加させると， D2ラマンピークの強度が増大することが報告されてお り, Si-O網目構造中の3員環構造等のより小さな環構造 の割合が相対的に増え，構造の緻密化が誘起されるため に屈折率が高くなると解釈されている8 同じように, 特にパルス間隔が長い(熱蓄積の効果が小 さい)場合, 偏光方向に依存してリターダンス, D2ピー ク強度に違いが見られた。 $\mathrm{E}=90^{\circ}$ の場合にリターダンス と D2ピークがより小さい值で飽和する原因は，次のよう に考えた， $\mathrm{E}=0^{\circ}$ と $\mathrm{E}=90^{\circ}$ において，偏光方向に対して パルス面の傾斜方向が異なることによって，レーザーの エネルギーが熱に変換される割合が変化し，特にレー ザー照射初期 $\left(N_{\text {pulse }}\right.$ が小さい場合)において, 急峻な温度 勾配に由来した内部応力の分布に違いが生じ, リターダ ンスやD2ピーク強度に違が現れたと考えられる ${ }^{28)}$.

これまでに筆者らは, ナノ周期構造による複屈折の遅 軸方向と位相差は，書き換え可能であること，石英ガラ ス内部に半永久的に記録可能であり, 空間の3次元 (XYZ) と組み合わせることによって，5次元光メモリ $(\mathrm{XYZ}+$ 偏光 + 位相差 $)$ としての応用が可能であること を示した ${ }^{29)}$ 。一例として, 石英ガラス内部に複屈折(位 相差と遅軸方向）からなる像を多層に描画した結果を Fig. 7に示す。上下層の影響なく描画および再生が可能 であることを確認している。このように屈折率変化だけ でなく，書き込まれた構造に由来した情報(複屈折の遅 軸方向と位相差)を最大限活用することによって，記録 密度はBlu-Rayの記録密度をはるかに上回る $300 \mathrm{Gbit} / \mathrm{cm}^{3}$ に達する可能性を見出した。

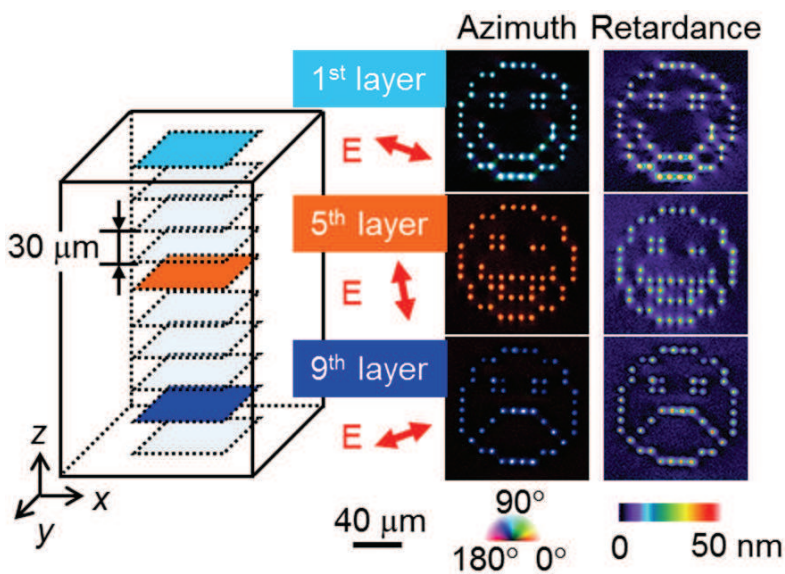

Fig. 7 Schematic of multilayer recording of "smiley" figures printed at different depths moving the focus and rotating the beam polarization direction. The layers with recorded figures are separated by $30 \mu \mathrm{m}$. Images of azimuth angle and retardance of the recorded planes in the multilayer observed by a polarized microscope are shown. The facial expression changes from "sad" to "smiley" with gradual decrease in depth of the sample.

\section{3. パルス面傾斜による光誘起ナノ周期構造の制御}

偏光方向とパルス面傾斜の相対関係に由来する非相反 的な現象は，フェムト秒レーザーに特徵的な現象である と考えられる。一般的なフェムト秒レーザーパルスの発 生は，チャープパルス増幅法が利用されている。このた め，グレーティングペアやプリズムペアの僅かなミスア ライメントに由来したごく小さなパルス面の傾きや空間 チャープが，その後の誘電体ミラーや対物レンズを通過 するうちに増幅され，場合によっては，集光部に誘起さ れる構造に変化が生じると考えられる。 パルス面傾斜に 由来した現象を詳しく評価するため，照射レーザー光の 偏光方向のみを変化させて石英ガラス内部に集光照射し た時のレーザー光の吸光度を測定した結果，吸収される レーザー光のエネルギーは偏光に依存し，照射パルスエ ネルギーに関係なく，同一の振幅，角周波数，位相の $\sin$ 関数 $\left(A=0.034 \sin \left(2 \pi \theta_{\mathrm{pol}}-\pi / 2\right)+C\right)$ でフィッティン グできた Fig. 8).

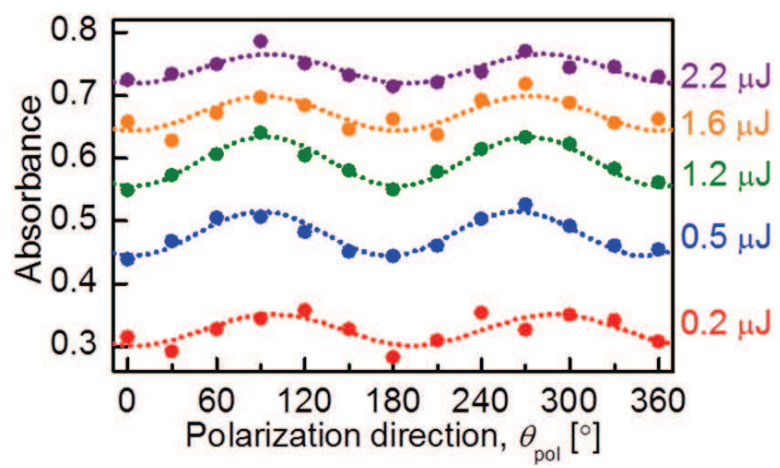

Fig. 8 Absorbance of incident laser intensity with different polarization directions. Dotted lines represent fitted curves by sine function with the same amplitude, angular frequency and phase. 
吸収されたレーザー光のエネルギーによって，次の2 種類の熱化が誘起されるためと考えられる. 一方は, 逆 制動放射を経て電子が加速されることによるガラスの等 方的な熱化であり, 我々の実験の場合, 偏光方向が 90 ○ の場合に相当する。 もう一方は, 偏光方向がレーザー光 のパルス面傾斜に平行な場合 (偏光方向は $0^{\circ}$ )において, プラズマ電子波との相互作用の結果，ガラス内部におい てキャビテーションや着色などを引き起こす異方性の強 い熱化である。このようなパルス面傾斜に由来した非相 反性は石英ガラスの場合, $1100{ }^{\circ} \mathrm{C} て ゙ 1$ 時間熱処理後も保 持されることを確認している。 このような 2 種類の熱化 プロセスによって, 最終的にガラス内部に誘起される構 造が異なることも観察している30). 以上のように，等方 性材料内部に同一パルスエネルギーのレーザー光を集光 する場合であっても，偏光方向とパルス面傾斜を制御す ることによって，書き込まれる構造制御が可能となり， 記録したビット情報においてもパルス面傾斜を利用した 制御が示唆される。

\section{4. まとめ}

現在のフェムト秒レーザーは，フォトンコストの面か ら考えると，実用上まだ問題があるものの，上述のよう に空間光位相変調器を活用することにより, 威力を発揮 しはじめている。ナノ周期構造に由来した光学異方性や パルス面傾斜による非相反性を最大限活用することに よって，5次元さらには6次元での記録も可能であり，今 後の発展が期待される.

\section{謝 辞}

本研究の一部は, 科学研究費補助金挑戦的萌芽研究に よった.ご討論頂いたサザンプトン大学 P. G. Kazansky 教授, 京都大学平尾一之教授に感謝する。

\section{参考文献}

1) O. M. Efimov, L. B. Glebov, S. Grantham, and M. Richardson: J. Non-Cryst. Solids 253 (1999) 58.

2) K. Kawamura, M. Hirano, T. Kurobori, D. Takamizu, T. Kamiya, and H. Hosono: Appl. Phys. Lett. 84 (2004) 311.

3) J. Qiu, X. Jiang, C. Zhu, M. Shirai, J. Si, N. Jiang, and K. Hirao: Angew. Chem., Int. Ed. 43 (2004) 2230.
4) H. Misawa: Japan Patent 08-220688 (1996).

5) K. M. Davis, K. Miura, N. Sugimoto, and K. Hirao: Opt. Lett. 21 (1996) 1729.

6) K. Miura, J. Qiu, H. Inouye, T. Mitsuyu, and K. Hirao: Appl. Phys. Lett. 71 (1997) 3329.

7) J. W. Chan, T. R. Huser, S. H. Risbud, and D. M. Krol: Appl. Phys. A 76 (2003) 367

8) W. J. Reichman, J. W. Chan, C. W. Smelser, S. J. Mihailov, and D. M. Krol: J. Opt. Soc. Am. B 24 (2007) 1627.

9) M. Sakakura, M. Terazima, Y. Shimotsuma, K. Miura, and K. Hirao: J. Appl. Phys. 109 (2011) 023503.

10) E. N. Glezer, M. Milosavljevic, L. Huang, R. J. Finlay, T.-H. Her, J. P. Callan, and E. Mazur: Opt. Lett. 21 (1996) 2023.

11) J. Qiu, K. Miura, and K. Hirao: Jpn. J. Appl. Phys. 37 (1998) 2263.

12) T. Tochio, M. Sakakura, Y. Shimotsuma, M. Nishi, K. Hirao, and K. Miura: Jpn. J. Appl. Phys. 51 (2012) 126602.

13) C. Hnatovsky, R. S. Taylor, P. P. Rajeev, E. Simova, V. R. Bhardwaj, D. M. Rayner, and P. B. Corkum: Appl. Phys. Lett. 87 (2005) 14104.

14) G. Cerullo, R. Osellame, S. Taccheo, M. Marangoni, D. Polli, R. Ramponi, P. Laporta, and S. D. Silverstri: Opt. Lett. 27 (2002) 1938.

15) H. Sun, Y. Xu, S. Juodkazis, K. Sun, M. Watanabe, S. Matsuo, H. Misawa, and J. Nishii: Opt. Lett. 26 (2001) 325.

16) P. G. Kazansky, H. Inouye, T. Mitsuyu, K. Miura, J. Qiu, K. Hirao, and F. Starrost: Phys. Rev. Lett. 82 (1999) 2199.

17) L. Sudrie, M. Franco, B. Prade, and A. Mysyrowicz: Opt. Commun. 191 (2001) 333.

18) B. C. Stuart, M. D. Feit, A. M. Rubenchik, B. W. Shore, and M. D. Perry: Phys. Rev. Lett. 74 (1995) 2248.

19) Y. Shimotsuma, P. G. Kazansky, J. Qiu, and K. Hirao: Phys. Rev. Lett. 24 (2003) 2474051.

20) Y. Shimotsuma, K. Hirao, J. Qiu, and P. G. Kazansky: Mod. Phys. Lett. B 19 (2005) 225.

21) V. R. Bhardwaj, E. Simova, P. P. Rajeev, C. Hnatovsky, R. S. Taylor, D. M. Rayner, and P. B. Corkum: Phys. Rev. Lett. 96 (2006) 057404.

22) T. Watanabe, T. Shintani, K. Ono, and T. Mine: IEICE Electron. Express 6 (2009) 1569

$23)$ E. Bricchi, B. G. Klappauf, and P. G. Kazansky: Opt. Lett. 29 (2004) 119.

24) A. Tonomura, J. Endo, T. Matsuda, T. Kawasaki, and H. Ezawa: Am. J. Phys. 57 (1989) 117.

25) M. Sakakura, M. Terazima, Y. Shimotsuma, K. Miura, and K. Hirao: Opt. Express 15 (2007) 16800.

26) I. Daniel, P. Gillet, B. T. Poe, and P. F. McMillan: Phys. Chem. Miner. 22 (1995) 74

27) P. F. McMillan, B. Piriou, and R. Couty: J. Chem. Phys. 81 (1984) 4234.

28) W. Yang, P. G. Kazansky, Y. Shimotsuma, M. Sakakura, K. Miura, and K. Hirao: Appl. Phys. Lett. 93 (2008) 171109.

29) Y. Shimotsuma, M. Sakakura, P. G. Kazansky, M. Beresna, J. Qiu, K. Miura, and K. Hirao: Adv. Mater. 22 (2010) 4039.

30) P. G. Kazansky, Y. Shimotsuma, M. Sakakura, M. Beresna, M. Gecevičius, Y. Svirko, S. Akturk, J. Qiu, K. Miura, and K. Hirao: Opt. Express 19 (2011) 20657. 